UCRL-JC-128223

Preprint

\title{
The Evaluation of Critical Pathways, Radionuclides, and Remedial Measures for Reducing the Radiological Dose to Returning Populations at a Former Nuclear Test Site
}

\author{
William L. Robison \\ Dr. Earl L. Stone \\ This paper was prepared for submittal to \\ HLW, LLW, Mixed Wastes and Environmental Restoration \\ -Working Towards a Cleaner Environment \\ Tucson, Arizona \\ March 1-5, 1998
}

November 1997

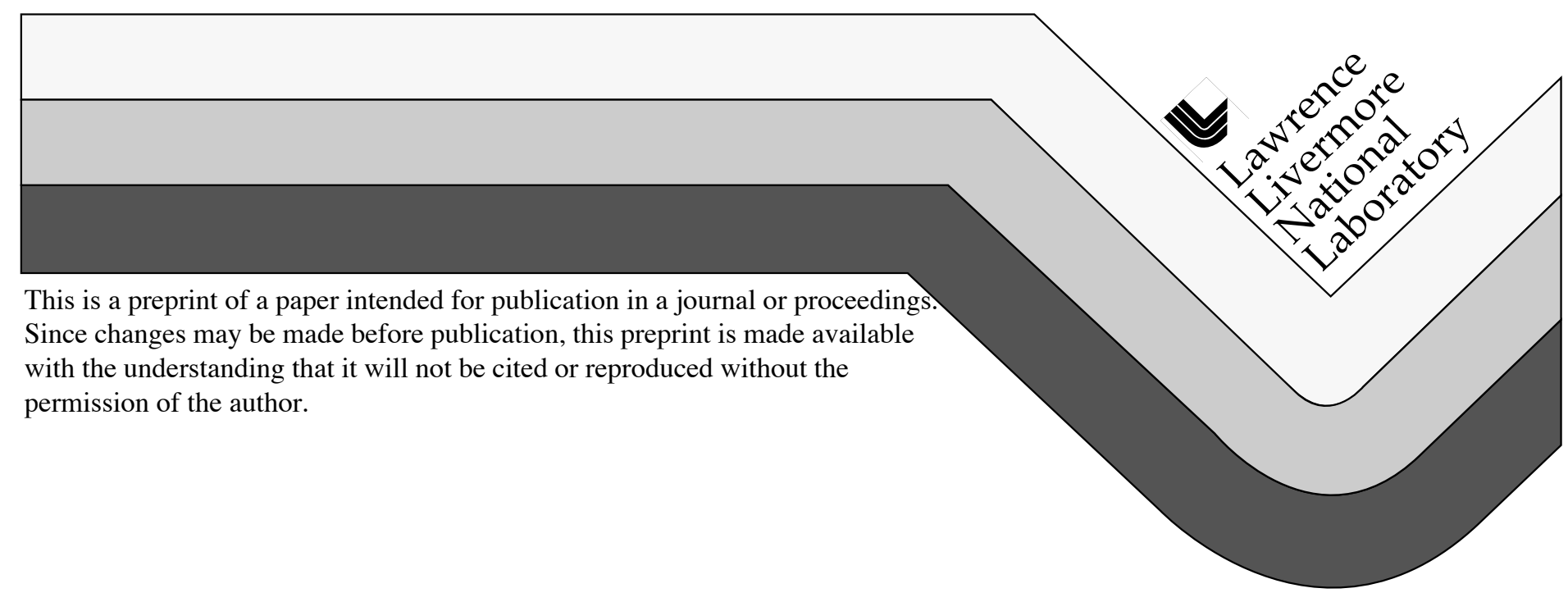




\section{DISCLAIMER}

This document was prepared as an account of work sponsored by an agency of the United States Government. Neither the United States Government nor the University of California nor any of their employees, makes any warranty, express or implied, or assumes any legal liability or responsibility for the accuracy, completeness, or usefulness of any information, apparatus, product, or process disclosed, or represents that its use would not infringe privately owned rights. Reference herein to any specific

commercial product, process, or service by trade name, trademark, manufacturer, or otherwise, does not necessarily constitute or imply its endorsement, recommendation, or favoring by the United States Government or the University of California. The views and opinions of authors expressed herein do not necessarily state or reflect those of the United States Government or the University of California, and shall not be used for advertising or product endorsement purposes. 
THE EVALUATION OF CRITICAL PATHWAYS, RADIONUCLIDES, AND REMEDIAL MEASURES FOR REDUCING THE RADIOLOGICAL DOSE TO RETURNING POPULATIONS AT A FORMER NUCLEAR TEST SITE

\author{
William L. Robison \\ Lawrence Livermore National Laboratory \\ P.O. Box 808, L-286 \\ Livermore, CA 94550-0808 \\ (510) 422-3884 \\ FAX: (510) 423-6785 \\ e-mail: robison1@llnl.gov \\ Dr. Earl L. Stone \\ University of Florida \\ Gainesville, FL
}

\begin{abstract}
Bikini Island, the major residence island at Bikini Atoll, was contaminated with radioactive fallout as a result of the BRAVO test conducted on March 1, 1954. We have identified the critical radionuclides and supplied radiological data needed to develop dose estimates for all possible exposure pathways. These estimates show that the major dose to returning populations would result from ingestion of cesium- $137\left({ }^{137} \mathrm{Cs}\right)$ in locally grownterrestrial foods where the predicted population average effective dose exceeds current federal guidelines. Consequently, we designed several long-term field experiments to develop and evaluate methods to reduce the ${ }^{137} \mathrm{Cs}$ content in locally grownfoods. This paper gives a general outline of the remediation experiments with a more detailed description of a preferred 'combined option'. Our comparative evaluation on various remedial methods show that the combined option-potassium treatment of the entire islands with limited excavation of soil in village and housing areas-will be effective in reducing the dose to about $10 \%$ of pretreatment levels, and offers very significant benefits with respect to adverse environmental impacts as well as savings in overall costs, time, and required expert resources.
\end{abstract}

\title{
INTRODUCTION
}

The United States conducted a nuclear testing program at Bikini and Enewetak Atolls in the Marshall Islands from 1946 through 1958 subsequent to relocating both communities. The BRAVO test on March 1, 1954 at Bikini Atoll yielded 15 MT, much above the expected yield of about 4 or 5 MT. The combination of the yield and wind directions led to contamination of Bikini Island, the main residential island, and also of inhabited atolls to the east of Bikini (Fig. 1). The Bikini people have had a continuingdesire to return to their home ever since the end of the test program.

The United States Atomic Energy Commission (AEC) initiated a general cleanup and planting of coconut, breadfruit, and Pandanus trees on Bikini Island in 1968. The island had been declared safe and a small part of the Bikini community resettled in 1970 and 1971.

A radiological survey in 1975 included external gamma measurements on a $50 \mathrm{~m}$ grid across the island and the collection of food crops then available, native vegetation, soil, and marine food species. However, there were too few samples of locally grown food crops to confidently establish PLACE FIG. 1 HERE] 
radionuclide concentrations needed for reliable dose estimates. Predictions based on the preliminary data indicated that when food crops were available for consumption, the body burden of ${ }^{137} \mathrm{Cs}$ and resulting doses would exceed federal guidelines [1]. This prediction was confirmed by Brookhaven National Laboratory (BNL) whole-body counting results in 1978 when coconuts began to fruit. The body burdens were above U.S. recommendations [2]. Consequently, in August 1978 Trust Territory officials relocated the people to Kili Island, and Ejet Island at Majuro Atoll.

Since that time, we have developed an extensive data base for ${ }^{137} \mathrm{Cs}$, strontium-90 $\left({ }^{90} \mathrm{Sr}\right.$ ), plutonium$239+240\left({ }^{239+240} \mathrm{Pu},\right)$ and americium-241 $\left({ }^{241} \mathrm{Am}\right)$ concentrations in the atoll ecosystem. We have collected and analyzed samples of soil, vegetation, animals, air, groundwater, cistern water and marine species in order to refine dose assessments for all exposure pathways. Such assessments are essential to define the critical radionuclides and pathways. They provide the communities with a basis for making informed decisions on resettlement options. They have also led to a research program evaluating the effectiveness of various remedial actions. This paper is a synopsis of previously reported data, some not widely known, plus additional findings as possible remedial measures.

\section{EXPOSURE PATHWAYS AND RADIONUCLIDES}

\section{External Gamma Exposure}

The external gamma exposure has been measured at all islands at Bikini Atoll by EG\&G, Inc. using an airborne gamma detection system [3]. Lawrence Livermore National Laboratory (LLNL) conducted a gamma survey on a $50 \mathrm{~m}$ grid across Bikini Island in 1975 [4]. The two surveys compared very well. More detailed gamma surveys have been conducted by LLNL inside and around the houses, and other village structures ${ }^{[5]}$.

\section{Radionuclides in Local Foods}

The surface soil of Bikini Island was contaminated with many radionuclides by the BRAVO detonation in 1954. Today, however, the only remaining radionuclides of any consequenceare ${ }^{137} \mathrm{Cs},{ }^{90} \mathrm{Sr},{ }^{239+240} \mathrm{Pu}$, and ${ }^{241} \mathrm{Am}$. Analyses of several thousand vegetation samples have led to the data in Table I.

The lagoon surface received close-in fallout from BRAVO just as the islands did. In addition, many other tests occurred in the lagoon or on the reef, possibly injecting more radionuclides into the sediment. Extensive sampling and analysis of the marine food species used in the Marshallese diet have produced the data shown in Table I.

\section{Inhalation of Resuspended Contaminated Soil}

The radionuclide concentration in the soil column reduces exponentially with depth as is demonstrated in Fig. 2. The highest radionuclide concentration is in the top $5 \mathrm{~cm}$. This is the source of potential exposure when respirable size soil particles with attached ${ }^{239+240} \mathrm{Pu}$ or ${ }^{241} \mathrm{Am}$ are resuspended by wind and/or mechanical disturbance. We have conducted detailed resuspension studies at 3 atolls to determine the amount of radioactivity that is resuspended and respirable in the atoll environment.

\section{[PLACE TABLE I AND FIG. 2 HERE]}




\section{Drinking Water and Ground Water}

The usual source of drinking and cooking water is rainfall collected into cisterns from the roofs of houses and community buildings. Thus, over the years we have collected samples and analyzed for ${ }^{137} \mathrm{Cs},{ }^{90} \mathrm{Sr}$, ${ }^{239+240} \mathrm{Pu}$ and ${ }^{241} \mathrm{Am}$. In the event of a drought, when fresh water catchment supplies are depleted, the people will use the fresh to slightly brackish water from the surface of the groundwater lens. Fresh water input to the lens occurs when the rainfall amounts are such that the water input exceeds the soil retention and evaportranspiration requirements. Since portions of the solubilized radionuclides in the soil are transported along with the water, the groundwater has a higher radionuclide concentration than the catchment water. The radionuclide concentrations in water are also listed in Table I.

\section{Diet Model}

The radiological dose assessment is based on the data developed from each of the exposure pathways and the diet model listed in Table I. The diet model we used provides for about $60 \%$ of the intake from imported foods and about $40 \%$ from local foods. The diet model is very important because the estimated dose will scale directly with the local food consumption. Details about the origins and development of the model can be found in Robison et al. $[5,6,7,8]$.

\section{Comparison of ${ }^{137} \mathrm{Cs}$ Body Burdens Derived from Environmental Data/Models with those Based on Whole Body Counting}

Our "environmental data/model" estimate of the ${ }^{137} \mathrm{Cs}$ body burden, which is proportional to dose, has been compared with the whole body counting body burden results obtained by BNL for the Rongelap and Utirik Atoll populations. The LLNL diet model, in conjunction with our environmental data for the two atolls, predicts the results from the BNL whole body measurements very closely over an 8 year period. Two other diet models that have been proposed lead to body burdens(i.e., dose) far in excess of those observed by whole body measurements [9]. A more detailed analysis of this validation is given in Robison and Sun [9].

\section{DOSEASSESSMENTMETHODOLOGY}

\section{External Dose}

Gamma Radiation-Current Island Conditions: The external exposure calculations for gamma radiation are based on measurements made on Bikini Island in 1978 and 1988 that are decay corrected to 1999. The following arbitrary daily distribution of time was used to develop the average external exposure: Ten hours are spent in the house where the exposure rate is $4.1 \times 10^{-10} \mathrm{C} \mathrm{kg}^{-1}\left(1.6 \mu \mathrm{R} \mathrm{h}^{-1}\right)$; nine hours around the house and village area where the exposure rate is assumed to be $2.2 \times 10^{-9} \mathrm{C} \mathrm{kg}^{-1}\left(8.5 \mu \mathrm{R} \mathrm{h}^{-1}\right)$ (weighted average of outside house and general village sites); three hours in the interior region of the island where the average exposure is $4.9 \times 10^{-9} \mathrm{C} \mathrm{kg}^{-1}\left(19 \mu \mathrm{R} \mathrm{h}^{-1}\right)$ [3]; two hours on the beach or lagoon where the exposure is $2.58 \times 10^{-11} \mathrm{C} \mathrm{kg}^{-1}\left(0.1 \mu \mathrm{R} \mathrm{h}^{-1}\right)$, based on EG\&G data [3]. Although the selection of this particular time distribution is arbitrary, discussions with Marshallese people and observations (while we have been in the islands) make the selection reasonable.

Gamma Radiation-Soil Removal in the Housingand Village Area: The interior portion of the island is assumed to remain the same, i.e., $\left.4.9 \times 10^{-9} \mathrm{C} \mathrm{kg}^{-1}(19 \mu \mathrm{R} \mathrm{h})^{-1}\right)$, as listed under the current conditions. 
The time distributions are also the same. The exposure rate in the village area and inside the houses after soil removal and placement of crushed coral on the groundsurface is $\left.5.2 \times 10^{-11} \mathrm{C} \mathrm{kg}^{-1}(0.2 \mu \mathrm{R} \mathrm{h})^{-1}\right)$ and $2.58 \times 10^{-11} \mathrm{C} \mathrm{kg}^{-1}\left(0.1 \mu \mathrm{R} \mathrm{h}^{-1}\right)$, respectively.

Beta Radiation: It is impossible to predict precisely what the beta dose to the skin will be, but it is clear that the "shallow dose" due to both beta particles and external gamma exposure will be only slightly greater than the dose estimated for external gamma whole-body exposure. This higher "shallow dose" will occur primarily to the most exposed parts of the body, usually the arms, lower legs, and feet. The skin is a much less sensitive organ to radiation than other parts of the body; consequently, the beta contribution to the total effective dose is extremely small. Detail on the beta dose measurements can be found in Singleton et al., and Robison et al. [10, 8].

\section{Internal Dose}

${ }^{137} \mathrm{Cs}$ : The conversion from the intake of ${ }^{137} \mathrm{Cs}$ to the dose equivalent for the adult is based upon the International Commission on Radiological Protection (ICRP) methods described in ICRP Publications 56, 61 [11, 12], which are based on Leggett's model [13]. In a separate report we estimated the comparative doses between adults and children [14]. The results indicate that the estimated integral effective dose for adults due to ingestion of ${ }^{137} \mathrm{Cs}$ and ${ }^{90} \mathrm{Sr}$ can be used as a conservative estimate for intake beginning at any other age. Here we calculate only the doses to adults.

${ }^{90} \mathrm{Sr}$ : The listed doses are calculated from the model developed by Leggett et al. [15], which is based on the structure and function of bone compartments as generally outlined in the ICRP model [11]. We refer the reader to the original articles and associated references for further information [15, 16]. (Doses listed in this paper are calculated from the Leggett model.)

\section{Transuranic Radionuclides $\left({ }^{239+240} \mathrm{Pu}\right.$ and $\left.{ }^{241} \mathrm{Am}\right)$}

Ingestion: We calculated the dose equivalent from ingestion of transuranic radionuclides $\left({ }^{239+240} \mathrm{Pu}\right.$ and ${ }^{241} \mathrm{Am}$ ) by ICRP methods [17, 18]. The amount of ingested plutonium or americium crossing the gut wall to the blood is assumed to be $5 \times 10^{-4}$ for Pu and Am in vegetation, and $10^{-5}[19]$ and $5 \times 10^{-4}$ for the fraction of $\mathrm{Pu}$ and $\mathrm{Am}$, respectively, ingested via soil. Of the fraction of $\mathrm{Pu}$ or Am reaching the blood, $45 \%$ is assumed to go to bone and $45 \%$ to the liver $[17,20]$. The biological half-life is $50 \mathrm{y}$ in bone and $20 \mathrm{y}$ in liver for both elements $[17,20]$. The quality factor is 20 for the alpha particles.

Inhalation: The dose equivalent from inhalation for the transuranic radionuclides is based on the intake determined from the assumptions discussed in Robison et al., [5], and the ICRP new lung model dose methodology $[17,11,20]$. The ${ }^{239+240} \mathrm{Pu}$ and ${ }^{241} \mathrm{Am}$ are considered class $\mathrm{W}$ particles, and the quality factor is 20 for the alpha particles. Other parameters are as described in the ICRP method previously discussed for the ingestion of transuranic radionuclides. The activity-median aerodynamic diameter (AMAD) is assumed to be $1 \mu \mathrm{m}$, which provides a slightly conservative dose estimate (i.e., slightly higher dose) because the observed AMAD was about $2.5 \mu \mathrm{m}$ in the Bikini experiment ${ }^{\text {[21] }}$.

\section{Body Weights and Biological Half-Life of ${ }^{137} \mathrm{Cs}$}

Data from BNL have been summarized to determine the body weights of the Marshallese people [22, 23, 24, 25, 2]. The average adult male body weight is $72 \mathrm{~kg}$ for Bikini, $71 \mathrm{~kg}$ for Enewetak, and $69 \mathrm{~kg}$ for 
Utirik. We have used $70 \mathrm{~kg}$ as the average male body weight in our calculations. The average biological half-life for the long-term compartment for ${ }^{137} \mathrm{Cs}$ in adults is listed as $110 \mathrm{~d}$ in ICRP [11] and NCRP [26]. This is consistent with the median of $115 \mathrm{~d}$ half-life obtained by BNL for 23 males [27, 28]. We used the $110 \mathrm{~d}$ half-life because it is based on a much larger sample population.

\section{DOSE ESTIMATES FOR CURRENT ISLAND CONDITIONS}

These doses are based on the diet listed in Table I which includes imported foods. If a diet of only local food were used, (even though such a diet is extremely unlikely today) the doses would be about a factor of 4 greater than those listed in the following tables.

The estimated maximum annual effective dose for residence on Bikini Island beginning in 1999 is shown in Table II. The maximum annual dose is defined here as the year in which the dose contribution from all exposure pathways and radionuclides is at maximum when using the intake parameters in our diet model and the mean value of the radionuclide concentrations in the foods, water and air. The estimated annual dose for Bikini without any type of remediation is $4.0 \mathrm{mSv}$.

The 30-, 50-, and 70-y integral effective doses for current island conditions are listed in Table III. The results indicate that about $90 \%$ of the estimated dose results from the ingestion of ${ }^{137} \mathrm{Cs}$. The second most significant dose is received via the external gamma pathway and is almost entirely the result of ${ }^{137} \mathrm{Cs}$ in the soil. The contribution of the other radionuclides to the total estimated dose over $70 \mathrm{y}$ is about $3 \%$. The contribution of each exposure pathway to the estimated dose is shown in Table IV. The terrestrial food chain is by far the most significant source of dose, and that contribution is due almost entirely to the uptake of ${ }^{137} \mathrm{Cs}$ into locally grownfood crops with their subsequentconsumptionby the people.

Based on the results of our dose assessment, it is clear that any effort to reduce the dose to people returning to live at the atoll should be directed toward the ${ }^{137} \mathrm{Cs}$ uptake into the terrestrial foods. In other words, if we could in some way greatly reduce the contribution of this pathway, we could essentially solve the dose issue for resettlement of the island.

\section{ENVIRONMENTAL LOSS OF ${ }^{137} \mathrm{Cs}$}

Natural processes also will reduce the estimated doses presented in this paper. For example, ${ }^{137} \mathrm{Cs}$ is transferred from soil to groundwater whenever sufficient rainfall occursto produce a recharge of the groundwater lens. The ${ }^{137} \mathrm{Cs}$ so transferred is no longer available for uptake by most plants. This continuing loss can be defined in terms of an environmental half-life analogous to the half-life of radioactive decay. Thus, the total loss of ${ }^{137} \mathrm{Cs}$ from the environment is the sum of these two processes. We are now in the process of evaluating data from Enewetak, Bikini, and Rongelap Atolls to determine the actual magnitude of the environmental loss. Some remedial measures are evaluated in light of this natural loss process.

\section{[PLACE TABLE II, III, \& IV HERE]}




\section{REMEDIALMEASURES}

\section{Removal of Contaminated Surface Soil}

Part of the cleanup of Enewetak Atoll in 1977-1979, entailed removal of surface soil from several islands to reduce the concentration of $\mathrm{Pu}$. Consequently, the Marshallese are aware of this option for removing radionuclides. It is also an easy option to understand and discuss. Disposal of the contaminated soil is not a trivial issue, but is beyond the scope of this paper. This method is definitely an effective way to reduce the radionuclide inventory on the island.

However, the environmental consequences of excavation are great and long-lasting. First, all vegetation must be removed. On Bikini Island, this would include some 25,000 producingcoconutpalms, breadfruit trees, Pandanus, papaya and other miscellaneous food crops, as well as native vegetation. Thus, scraping off the surface $40 \mathrm{~cm}$ would indeed remove the radionuclides, but with them the organic layer developed over centuries. Not only does the organic layers provide nutrient exchange capacity and greatly increase rainfall retention, but it also stabilizes the surface against wind and water erosion, and renders the soil friable for root development. No island-wide inventories are available, but some of the organic-rich soils contain upwards of $5,000 \mathrm{~kg} \mathrm{ha}^{-1} \mathrm{~N}$ and even $10,000 \mathrm{~kg} \mathrm{ha}^{-1} \mathrm{P}$. The cost of these elements in a fertilizer bag would be several thousand dollars per hectare.

Some of our studies have demonstrated how the barren scraped surface could be revegetated. Restoring and maintaining productivity, however, requires a decades-long commitment of effort and expertise that is far from assured. In any case, the long term costs of restoration are above and beyond the $\$ 100 \mathrm{M}$ dollars estimated to excavate only the one square mile of surface of Bikini Island [29].

Because of the severe environmental impacts of the excavation option, we have examined other remedial possibilities that might reduce ${ }^{137} \mathrm{Cs}$ in the terrestrial food chain.

\section{Leaching ${ }^{137} \mathrm{Cs}$ from the Soil}

A large-scale field irrigation experiment was designed to determine whether a significant fraction of the ${ }^{137} \mathrm{Cs}$ inventory in the soil could be removed by leaching. Atolls simply do not have the large stores of fresh water needed for a single, let alone multiple leachings. On the other hand, the supply of seawater is boundless, and the contained cations might be expected to dislodge any cesium held by simple exchange forces.

The adverse consequences of such treatment are the destruction of the freshwater lens and salinization of the soil itself. However, the latter turned out to be a short-lived effect, whereas restoration of the freshwater lens takes much longer.

In the experiment, we sprayed approximately $80^{\prime \prime}$ of sea water on three occasions at two month intervals on a one hectare area while monitoring the downward movement of both sea water and ${ }^{137} \mathrm{Cs}$. (Fig. 3) The initial pulse of ${ }^{137} \mathrm{Cs}$ into the ground water diminished in magnitude with each application, and represented only the small fraction that was soluble or readily exchangeable. A final total application of 20 meters (depth) of seawater removed only 3-5\% of the total ${ }^{137}$ Cs inventory. Laboratory experiments with large soil columns gave similar results. 
Although $95-97 \%$ of the ${ }^{137} \mathrm{Cs}$ remained, plant regrowth after rains leached the soil contained very little ${ }^{137}$ Cs. Plant concentrations increased over the next 24 months, however, and eventually returned to pre-irrigation values, demonstrating renewed availability.

The large effort required for such a small reduction in ${ }^{137} \mathrm{Cs}$ inventory obviously eliminates the treatment as a remedial measure.

\section{Immobilization of ${ }^{137} \mathrm{Cs}$ in Soil}

An alternative to removing ${ }^{137} \mathrm{Cs}$ or the soil itself would be to immobilize ${ }^{137} \mathrm{Cs}$ against plant root uptake. We conductedexploratory studies with two materials: finely grounddioctyhedral mica as a surrogate for silicate clays, and clinoptilolite, a commercially available zeolite. Both bind ${ }^{137} \mathrm{Cs}$ so tightly that it is largely unabsorbed by plant roots.

Mica: We applied mica at the rate of $6,000 \mathrm{~kg} \mathrm{ha}^{-1}$ uniformly over the soil surface of a productive coconut grove. The aim was to immobilize any available $\mathrm{Cs}$ already at the surface and thus gradually interrupt cycling of ${ }^{137} \mathrm{Cs}$ from plant to soil to plant again. We now know that some mica has penetrated into the 5-10 $\mathrm{cm}$ depth of soil, hastening its effectiveness. Sampling of coconuts indicates a reduction in ${ }^{137} \mathrm{Cs}$ after 8 years or so. The reduction in shallow rooted herbaceous vegetation without the large internal inventory of ${ }^{137} \mathrm{Cs}$ is more impressive. For the grass Eustachys Petraea, the ${ }^{137} \mathrm{Cs}$ concentration in November 1987 was $1.3 \mathrm{~Bq} \mathrm{~g}^{-1}$ in the mica treated plot and $9.1 \mathrm{~Bq} \mathrm{~g}^{-1}$ in the control plot. In November 1990, the mica treated and control plot concentrations were $2.0 \mathrm{~Bq} \mathrm{~g}^{-1}$ and $7.4 \mathrm{~Bq} \mathrm{~g}^{-1}$, respectively.

Clinoptilolite_: The zeolite study entailed addition of clinoptilolite at the rate of 20,40, and $80 \mathrm{mt}^{-1}$ to soil in small plots. The upper $30 \mathrm{~cm}$ of soil and clinoptilolite were mixed in a cement mixer achieving a far more intimate contact and distribution than would be possible in field scale application. Since the clinoptilolite itself contains appreciable $\mathrm{K}$ with some availability to plants, the study included both a conventional control and a control with added K.

We grew six successive crops on these plots, including corn and sweet potatoes. Combining mass production of the fifth and sixth crops, seedling and ratoon crops of sorghum from the same root system, illustrates treatment effects:

Using the control plus a moderate application of $\mathrm{K}$ as a standard, this conventional control (without added K) yielded only $61 \%$ as much biomass, but it contained $170 \%$ more ${ }^{137} \mathrm{Cs}$. On the other hand, biomass yields at the lowest clinoptilolite were about equal, but contained only $71 \%$ as much ${ }^{137} \mathrm{Cs}$, or only $41 \%$ as much as the conventional control. The highest rate of clinoptilolite produced about twice the biomass as the control, but contained only $12 \%$ as much ${ }^{137} \mathrm{Cs}$ (or $6 \%$ of the control concentration). Thus, application of either mica or clinoptilolite, (and related clays with zeolites) are capable of immobilizing ${ }^{137} \mathrm{Cs}$ in soil. Nevertheless, the studies involved large quantities of materials plus either intensive mixing with bare soil as rather long reaction times. Moreover, immobilization counter acts natural leaching, and largely eliminates removal indicated by an environmental half-life. 


\section{RemovalbyContinuousCropping}

A frequently proposed concept for reducing the ${ }^{137} \mathrm{Cs}$ inventory in soil is to repeatedly grow and dispose of successive crops of some plants that have a high uptake of the element. Consideration of plant growth factors on atolls demonstrates the limited application of the concept.

The source of fresh water is rainfall that occurs mostly from June through November, which limits natural vegetation growth to that six month interval. The average annual mass of vegetation that can be produced is about $1 \mathrm{~kg} \mathrm{~m}^{-2}$ or perhaps even less with continued cropping. The maximum uptake of ${ }^{137} \mathrm{Cs}$ in vegetation expressed as a concentration ratio $\left(\mathrm{Bq} \mathrm{g}^{-1}\right.$ in plants (wet weight)/Bq $\mathrm{g}^{-1}$ in soil (dry weight) is about 3. A square meter of soil, $40 \mathrm{~cm}$ deep, weights about $440 \mathrm{~kg}$. Thus, the loss of ${ }^{137} \mathrm{Cs}$ is:

$$
\frac{1 \mathrm{~kg} \text { vegetation } \mathrm{y}^{-1} \times 3}{440 \mathrm{~kg} \text { soil }}=0.0068 \mathrm{y}^{-1}
$$

Also, whole coconuttrees have been analyzed to determine the ${ }^{137} \mathrm{Cs}$ concentration in each component, and litter fall (fronds and coconuts)has been quantified to determine the annual loss of ${ }^{137} \mathrm{Cs}$ in the coconutgrove if all the litter were collected and disposed of during the year. This loss rate is $\lambda=$ $0.0063 \mathrm{y}^{-1}$, which is similar to the loss calculated above if annual plants covered the entire island.

Over 90 y radioactive decay $\left(\lambda=0.023 \mathrm{y}^{-1}\right)$ reduces the inventory of ${ }^{137} \mathrm{Cs}$ to $12 \%$ of its initial value. The decay constant for both processes is $\lambda=0.023+0.0068 \cong 0.030 \mathrm{y}^{-1}$ which over $90 \mathrm{y}$ reduces the ${ }^{137} \mathrm{Cs}$ inventory to $6.7 \%$ of its initial value. Thus, cropping the entire island for $90 \mathrm{y}$ and disposing of the vegetation in some manner-an enormoustask- would achieve only an additional $6 \%$ loss of ${ }^{137} \mathrm{Cs}$. Practically, this would never happen. Moreover, our field experiments demonstrate that repeated cropping depletes the pool of available potassium so that growth greatly diminishes. This is a selfdefeating cycle. Adding $\mathrm{K}$ to increase productivity reduces the ${ }^{137} \mathrm{Cs}$ concentration in plants (see previous and next sections), and consequently, the total removal of ${ }^{137} \mathrm{Cs}$ by cropping becomes miniscule.

\section{Potassium (K) Treatment}

The mineral matrix in soils in deep ocean atolls consist almost entirely of sands and gravels of calcite and aragonite containing small amounts of substituted $\mathrm{Mg}$ and Sr. Silicate clays are undetectable and the sole source of cation exchange capacity is organic matter. Total potassium content is the order of 300 $\mathrm{mg} \mathrm{kg}^{-1}$ [30]. Exchangeable $\mathrm{K}$ in the upper $25 \mathrm{~cm}$ of soil averages only $30-40 \mathrm{mg} \mathrm{kg}^{-1}$, with the higher concentrations in the upper $5 \mathrm{~cm}$ of soil. The major source of $\mathrm{K}$ available to plants derives from oceanic spray rather than mineral weathering.

We have conducted many large-scale field-scale experiments with coconut and other plants evaluating the effect of $\mathrm{K}$ additions, their times of application, and the longevity of the effect [31]. Fig. 4 illustrates some of the results obtained when 1260 and $2520 \mathrm{~kg} \mathrm{ha}^{-1}$ of $\mathrm{K}$ were added to a portion of the coconut grove. In a separate experiment the addition of $440 \mathrm{~kg} \mathrm{ha}^{-1}$ reduced the ${ }^{137} \mathrm{Cs}$ in coconutsto about $20 \%$ of pretreatment levels. Near maximumeffectiveness is achieved with the addition of the 1260 and $2520 \mathrm{~kg} \mathrm{ha}^{-1}$ which reduce the ${ }^{137} \mathrm{Cs}$ in coconuts to about $5 \%$ of pretreatment levels. These results are reflected in the "Scope +K Option" column in Table I. Such reduction endures because K content increases and ${ }^{137} \mathrm{Cs}$ content decreases in the large stem. Ten years after application of $2500 \mathrm{~kg} \mathrm{ha}^{-1}$ of $\mathrm{K}$, the ${ }^{137} \mathrm{Cs}$ 
concentration in coconut meat is only about $2 \mathrm{~Bq} \mathrm{~g}^{-1}$ versus an original concentration of about $8 \mathrm{~Bq} \mathrm{~g}^{-1}$ and low point of less than $1 \mathrm{~Bq} \mathrm{~g}^{-1}$.

The large and prompt reduction of ${ }^{137} \mathrm{Cs}$ in coconuts and all other food crops tested, the ease of application, and the relatively low cost makes $\mathrm{K}$ addition the preferred treatment option although this was known 12 years ago. Added $\mathrm{K}$ also increases growth and productivity of plants on the island.

\section{[PLACE FIG.4]}

Consequently, we have developed a "combined option" that we have presented to the communities consisting of $\mathrm{K}$ treatment over most of the island with limited excavation of the surface soil in the hosing and village area. Such excavation significantly reduces the external gamma dose and the exposure to ${ }^{239+240} \mathrm{Pu}$ and ${ }^{241} \mathrm{Am}$ in those places where adults and children spend most of their time.

The "combined option" reduces the estimated maximum annual effective dose from $4.0 \mathrm{mSv}$ y-1 (Table I) to about $0.4 \mathrm{mSv} \mathrm{y}^{-1}$. The 30-, 50-, and 70-y integral effective doses (Table V) are $9.8 \mathrm{mSv}, 14 \mathrm{mSv}$, and $16 \mathrm{mSv}$, respectively. A comparison between pre-treatment and post-treatment effective doses is given in Table VI. The "combined option" leads to estimated dose about a factor of 10 below the estimates for current island conditions.

The background effective dose in the Marshall Islands from both external and internal exposure is about $2.4 \mathrm{mSv} \mathrm{y}^{-1}[8]$. The estimated total maximumannual effective dose for a returning population is then $2.4+0.41=2.8 \mathrm{mSv} \mathrm{y}^{-1}$. For comparison, the average annual effective background dose for Europe is about $2.4 \mathrm{mSv}{ }^{[32]}$ and for the U.S. about $300 \mathrm{mSv}$ [33]. Consequently, the "combined option" will lead to total doses on Bikini Island that are similar to background doses around the world. People in some areas of the world live with background doses of $1000 \mathrm{mSv}$ or more [33].

\section{RECOMMENDATIONSTOTHEATOLLCOMMUNITIES}

The remedial options discussed with the communities over the last several years are limited to the excavation option and "combined option." The excavation option was the primary focus of the communities for years and, with all its inherent adverse environmental consequences,is still much discussed. More recently, much more attention has been given to the "combined option" which for most of the islands does not remove the ${ }^{137} \mathrm{Cs}$ (or other radionuclides), but simply prevents the uptake into foods until radiological decay reduces the nuclides to insignificant levels. Both the Bikini and Rongelap communities are now giving serious thought to this option.

Ultimately, it is their decision on which rehabilitation plan they will use. But in addition to doing the science, it is our job to discuss with them the plus and minuses of the options so they fully understand the ramifications of each in order to make an informed decision. This has led to many meetings with the communities over the last several years.

Acknowledgment-This work is performed under the auspices of the U.S. Department of Energy at Lawrence Livermore National Laboratory under contract W-7405-Eng-48.

[PLACE TABLE V AND VI HERE]

\section{REFERENCES}

1. W.L. ROBISON, W.A. PHILLIPS, and C.S. COLSHER, "Dose Assessment at Bikini Atoll," UCRL-51879, Pt. 5, Lawrence Livermore National Laboratory (1977). 
2. R.P. MILTENBURGER, N.A. GREENHOUSE, and E.T. LESSARD, "Whole-Body Counting Results from 1974 to 1979 for Bikini Island Residents," Health Physics 39:177-183.

3. W.J. TIPTON, and R.A. MEIBAUM, "An Aerial Radiological and Photographic Survey of Eleven Atolls and Two Islands within the Northern Marshall Islands, EGG-1183-1758, EG\&G, Las Vegas, NV (1981).

4. P.H. GUDIKSEN, T.R. CRITES, and W.L. ROBISON, “External Dose Estimated for Future Bikini Atoll Inhabitants," UCRL-51879, Rev. 1, Lawrence Livermore National Laboratory (1976).

5. W.L. ROBISON, K.T. BOGEN, and C.L. CONRADO, "An Updated Dose Assessment for Resettlement Options at Bikini Atoll—A U.S. Nuclear Test Site," Health Physics 73(1): 100-114 (1997).

6. W.L. ROBISON, W.A. PHILLIPS, M.E. MOUNT, B.R. CLEGG, and C.L. CONRADO, "Reassessment of the Potential Radiological Doses for Residents Resettling Enewetak Atoll, UCRL-53066, Lawrence Livermore National Laboratory (1980).

7. W.L. ROBISON, C.L. CONRADO, and W.A. PHILLIPS, “Enjebi Island Dose Assessment," UCRL53805, Lawrence Livermore National Laboratory (1987).

8. W.L. ROBISON, C.L. CONRADO, and K.T. BOGEN, “An Updated Dose Assessment for Rongelap Island," UCRL-LR-107036, Lawrence Livermore National Laboratory (1994).

9. W.L. ROBISON and C. SUN, "The Use of Comparative ${ }^{137} \mathrm{Cs}$ Body Burden Estimates from Environmental Data/Models and Whole Body Counting to Evaluate Diet Models for the Ingestion Pathway," Health Physics 73(1): 152-166 (1997).

10. K.L. SHINGLETON, J.L. CATE, M.G. TRENT, and W.L. ROBISON, “Bikini Atoll Ionizing Radiation Survey May 1985-May 1986," UCRL-53798, Lawrence Livermore National Laboratory (1987).

11. INTERNATIONAL COMMISSION ON RADIOLOGICAL PROTECTION (ICRP), "Age-Dependent Doses to Members of the Public from Intake of Radionuclides," ICRP Publication 56, Part 1., Pergamon Press, New York, NY (1990).

12. INTERNATIONAL COMMISSION ON RADIOLOGICAL PROTECTION (ICRP), "Annual Limits of Intake of Radionuclides by Workers Based on the 1990 Recommendations," ICRP Publication 61, Pergamon Press, New York, NY (1991).

13. R.W. LEGGETT, "Predicting the Retention of Cesium in Individuals," Health Physics 50: 747-759 (1986).

14. W.L. ROBISON and W.A. PHILLIPS, "Estimates of the Radiological Dose from Ingestion of 137Cs and 90Sr to Infants, Children, and Adults in the Marshall Islands," UCRL-53917, Lawrence Livermore National Laboratory (1989).

15. R.W. LEGGETT, K.F. ECKERMAN, and L.R. WILLIAMS, "Strontium-90 in Bone: A Case Study in Age-Dependent Dosimetric Modeling," Health Physics 43: 307-322 (1982).

16. M.R. CHRISTY, W. LEGGETT, D.E. DUNNING JR, and K.F. ECKERMAN, “Age-Dependent DoseConversion Factors for Selected Bonej-Seeking Radionuclides," NUREG/CR-3535, ORNL/TM-8929, Nuclear Regulatory Commission (1984).

17. INTERNATIONAL COMMISSION ON RADIOLOGICAL PROTECTION (ICRP), “The Metabolism of Plutonium and Related Compounds," Publication 48, Pergamon Press, Oxford, UK (1986).

18. INTERNATIONAL COMMISSION ON RADIOLOGICAL PROTECTION (ICRP), "Limits for Intakes of Radionuclides by Workers: An addendum," Publication 30, Part 4, Pergamon Press, New York, NY (1988). 
19. J.D. HARRISON, G.P.L. NAYLOR, and J.W. STATHER, “Gastrointestrial Absorption of Plutonium and Americium in Rats and Guinea Pigs after Ingestion of Dusts from the Former Nuclear Weapons Test Site at Marolinga: Implication for Human Exposure," NRPB-M196, Radiation Protection Board, Chilton, Didcot, Oxon (1989).

20. INTERNATIONAL COMMISSION ON RADIOLOGICAL PROTECTION (ICRP), "Age-Dependent Doses to Members of the Public from Intake of Radionuclides: Part 2 Ingestion Dose Coefficients," Publication 67, Pergamon Press, New York, NY (1993).

21. J.H. SHINN, D.N. HOMAN, and W.L. ROBISON, "Resuspension Studies in the Marshall Islands," Health Physics 73(1): 248-257 (1997).

22. R.A. CONARD, J.S. ROBERTSON, L.M. MEYER, W.W. SUTOW, W. WOLLINS, A. LOWERY, H.C. BRSCHEL JR, J.M. BARTON, M. GOLDMAN, H. HECHTER, M. EICHER, R.K. CARVER, P.W. POTTER, "Medical Survey of Rongelap People, March 1958, Four Years after Exposure to Fallout," BNL-534, Brookhaven National Laboratory (1959).

23. R.A. CONARD, H.E. MACDONALD, A. LOWERY, L.M. MEYER, W.W. SUTOW, B.S. BLUMBERG, J.W. HOLLINGSWORTH, H.W. LYON, W.H. LEWIS JR, A.A. JAFFEE, M. EICHER, D. POTTER, LANWI II, E. RIKLON, J. IAMAN, J., HELKEW, "Medical Survey of Rongelap People Five and Six Years after Exposure to Fallout," BNL-780, Brookhaven National Laboratory (1960).

24. R.A. CONARD et al., "Medical Survey of Rongelap People Eight Years after Exposure to Fallout," BNL-780, Brookhaven National Laboratory (1963).

25. R.A. CONARD, K. KNUDSEN, and B.M. DOBYNS, "A Twenty-Year Review of Medical Findings in the Marshallese Population Accidentally Exposed to Radioactive Fallout," BNL-50424, Brookhaven National Laboratory (1975).

26. NATIONAL COUNCIL ON RADIATION PROTECTION AND MEASUREMENTS (NCRP), "Cesium-137 from the Environment to Man: Metabolism and Dose," NCRP-52, National Council on Radiation Protection and Measurements, Washington, DC (1977).

27. R. MILTENBERGER, E. LESSARD, and N.A. GREENHOUSE, "Cobalt-60 and Cesium-137 Long Term Biological Removal Rate Constants for the Marshallese Population," Health Physics 40(5): 615-623 (1981).

28. R. MILTENBERGER and E. LESSARD, "Body Burden and Dose Assessment for Bikini Island Residents 1969-1980," Private Communication, Brookhaven National Laboratory (1987).

29. BIKINI ATOLL REHABILITATION COMMITTEE (BARC), "Report No. 4, Status March 31, 1986," Submitted March 31, 1966 to the U.S. Congress, House and Senate Committees on Interior Appropriations, pursuant to House Report 99-450, Department of Interior, AccountNo. TT-1580X08 (1986).

30. F.R. FOSBERG and D. CARROLL, "Terrestrial Sediments and Soils of the Northern Marshall Islands," Atoll Res. Bull 113 (1965).

31. W.L. ROBISON and E.L. STONE, "The Effect of Potassium on the Uptake of ${ }^{137} \mathrm{Cs}$ in Food Crops Grown on Coral Soils: Coconut at Bikini Atoll," Health Physics 62(6): 496-511 (1992).

32. UNITED NATIONS SCIENTIFIC COMMITTEE ON THE EFFECTS OF ATOMIC RADIATION (UNSCEAR), "Sources Effects, and Risks of Ionizing Radiation," United Nations sales publication E.77.IX.1, United Nations, New York, NY, Report to the General Assembly with annexes (1993).

33. NATIONAL COUNCIL ON RADIATION PROTECTION AND MEASUREMENTS (NCRP), "Exposure of the Population in the United States and Canada from Natural Background Radiation," NCRP Report No. 94, NCRP, Bethesda, MD (1987). 


\begin{tabular}{|c|c|c|c|c|c|c|c|}
\hline \multirow{3}{*}{ Local Food } & & & \multicolumn{5}{|c|}{ Specific Activity in 1999, in (Bq g ${ }^{-1}$ wet wt.) } \\
\hline & \multicolumn{2}{|c|}{$\begin{array}{c}\text { Imported Foods } \\
\text { Diet }\end{array}$} & \multirow{2}{*}{$\begin{array}{cc}\begin{array}{c}\text { Current } \\
\text { Conditions }\end{array} \\
1{ }^{137} \mathrm{Cs}\end{array}$} & \multirow{2}{*}{$\begin{array}{c}\text { Scrape + } \\
\text { K Option } \\
{ }^{137} \mathrm{Cs}\end{array}$} & \multicolumn{3}{|c|}{$\begin{array}{c}\text { Common to Both } \\
\text { Current \& Scrape + K Option }\end{array}$} \\
\hline & $\mathrm{gd}^{-1}$ & Kcal d ${ }^{-1}$ & & & ${ }^{90} \mathrm{Sr}$ & $239+240 \mathrm{Pu}$ & ${ }^{241} \mathrm{Am}$ \\
\hline $\begin{array}{l}\text { Reef fish } \\
\text { Tuna } \\
\text { Mahi Mahi } \\
\text { Marine Crabs } \\
\text { Lobster } \\
\text { Clams } \\
\text { Trochus } \\
\text { Tridacna Muscle } \\
\text { Iedrul } \\
\text { CoconutCrabs } \\
\text { Land Crabs } \\
\text { Octopus } \\
\text { Turtle } \\
\text { Chicken Muscle } \\
\text { Chicken Liver } \\
\text { Chicken Gizzard } \\
\text { PorkMuscle } \\
\text { Pork Kidney } \\
\text { Pork Liver } \\
\text { Pork Heart } \\
\text { Bird Muscle } \\
\text { Bird Eggs } \\
\text { Chicken Eggs } \\
\text { TurtleEggs } \\
\text { Pandanus Fruit } \\
\text { Pandanus Nuts } \\
\text { Breadfruit } \\
\text { Coconutuice } \\
\text { Coconut Milk } \\
\text { Tuba/Jekero } \\
\text { Drinking Coco Meat } \\
\text { Copra Meat } \\
\text { Sprout.Coco } \\
\text { Marshallese Cake } \\
\text { Papaya } \\
\text { Squash } \\
\text { Pumpkin } \\
\text { Banana } \\
\text { Arrowroot } \\
\text { Citrus } \\
\text { Rainwater } \\
\text { Wellwater } \\
\text { Malolo (cool aid) } \\
\text { Coffee/Tea } \\
\text { Soila } \\
\text { Soilb } \\
\text { Total Local } \\
\text { arda }\end{array}$ & $\begin{array}{l}24.2 \\
13.9 \\
3.56 \\
1.68 \\
3.88 \\
4.56 \\
0.10 \\
1.67 \\
3.08 \\
3.13 \\
0.00 \\
4.51 \\
4.34 \\
8.36 \\
4.50 \\
1.66 \\
5.67 \\
\mathrm{NR} \\
2.60 \\
0.31 \\
2.71 \\
1.54 \\
7.25 \\
9.36 \\
8.66 \\
0.50 \\
27.2 \\
99.1 \\
51.9 \\
0.00 \\
31.7 \\
12.2 \\
7.79 \\
11.7 \\
6.59 \\
\mathrm{NR} \\
1.24 \\
0.020 \\
3.93 \\
0.10 \\
313 \\
207 \\
199 \\
228 \\
0.10 \\
0.10 \\
1322\end{array}$ & \begin{tabular}{|l|}
33.8 \\
19.4 \\
3.92 \\
1.51 \\
3.49 \\
3.65 \\
0.080 \\
2.14 \\
2.46 \\
2.19 \\
0.00 \\
4.51 \\
3.86 \\
14.2 \\
7.38 \\
2.46 \\
25.5 \\
0.00 \\
6.27 \\
0.60 \\
4.61 \\
2.31 \\
11.8 \\
14.0 \\
5.20 \\
1.33 \\
35.3 \\
10.9 \\
179 \\
0.00 \\
32.3 \\
50.3 \\
6.23 \\
39.2 \\
2.57 \\
0.00 \\
0.37 \\
0.018 \\
13.6 \\
0.049 \\
0.00 \\
0.00 \\
0.00 \\
0.00 \\
0.00 \\
0.00 \\
547
\end{tabular} & $\begin{array}{l}7.9 \times 10^{-3} \\
4.5 \times 10^{-3} \\
4.5 \times 10^{-3} \\
1.4 \times 10^{-3} \\
1.4 \times 10^{-3} \\
4.6 \times 10^{-4} \\
4.6 \times 10^{-4} \\
4.6 \times 10^{-4} \\
4.6 \times 10^{-4} \\
3.7 \times 10^{-1} \\
3.7 \times 10^{-1} \\
1.8 \times 10^{-3} \\
2.8 \times 10^{-4} \\
1.5 \times 10^{-1} \\
1.5 \times 10^{-1} \\
1.5 \times 10^{-1} \\
7.0 \times 10^{0} \\
6.5 \times 10^{0} \\
3.6 \times 10^{0} \\
4.2 \times 10^{0} \\
2.5 \times 10^{-3} \\
6.7 \times 10^{-4} \\
1.5 \times 10^{-1} \\
2.8 \times 10^{-4} \\
3.9 \times 10^{0} \\
3.9 \times 10^{0} \\
3.8 \times 10^{-1} \\
1.2 \times 10^{0} \\
5.4 \times 10^{0} \\
5.4 \times 10^{0} \\
2.9 \times 10^{0} \\
5.4 \times 10^{0} \\
5.4 \times 10^{0} \\
5.4 \times 10^{0} \\
2.2 \times 10^{0} \\
1.2 \times 10^{0} \\
1.2 \times 10^{0} \\
1.8 \times 10^{-1} \\
5.4 \times 10^{-2} \\
1.2 \times 10^{-1} \\
4.3 \times 10^{-5} \\
4.5 \times 10^{-3} \\
4.3 \times 10^{-5} \\
4.3 \times 10^{-5} \\
1.3 \times 10^{0}\end{array}$ & $\begin{array}{l}.9 \times 10^{-3} \\
4.5 \times 10^{-3} \\
4.5 \times 10^{-3} \\
1.4 \times 10^{-3} \\
1.4 \times 10^{-3} \\
4.6 \times 10^{-4} \\
4.6 \times 10^{-4} \\
4.6 \times 10^{-4} \\
4.6 \times 10^{-4} \\
3.7 \times 10^{-1} \\
3.7 \times 10^{-1} \\
1.8 \times 10^{-3} \\
2.8 \times 10^{-4} \\
2.1 \times 10^{-2} \\
2.1 \times 10^{-2} \\
2.1 \times 10^{-2} \\
1.6 \times 10^{0} \\
1.4 \times 10^{0} \\
8.1 \times 10^{-1} \\
9.8 \times 10^{-1} \\
2.5 \times 10^{-3} \\
6.7 \times 10^{-4} \\
2.1 \times 10^{-2} \\
2.8 \times 10^{-4} \\
1.9 \times 10^{-1} \\
1.9 \times 10^{-1} \\
1.9 \times 10^{-2} \\
5.8 \times 10^{-2} \\
2.7 \times 10^{-1} \\
2.7 \times 10^{-1} \\
1.5 \times 10^{-1} \\
2.7 \times 10^{-1} \\
2.7 \times 10^{-1} \\
2.7 \times 10^{-1} \\
1.1 \times 10^{-1} \\
5.9 \times 10^{-2} \\
5.9 \times 10^{-2} \\
8.9 \times 10^{-3} \\
5.4 \times 10^{-2} \\
6.0 \times 10^{-3} \\
4.3 \times 10^{-5} \\
4.5 \times 10^{-3} \\
4.3 \times 10^{-5} \\
4.3 \times 10^{-5} \\
3.9 \times 10^{-1} \\
\end{array}$ & $\begin{array}{l}4.5 \times 10^{-5} \\
5.3 \times 10^{-6} \\
5.3 \times 10^{-6} \\
8.9 \times 10^{-5} \\
8.9 \times 10^{-5} \\
8.7 \times 10^{-5} \\
8.7 \times 10^{-5} \\
8.7 \times 10^{-5} \\
8.7 \times 10^{-5} \\
5.2 \times 10^{-2} \\
5.2 \times 10^{-2} \\
4.5 \times 10^{-5} \\
4.5 \times 10^{-5} \\
1.5 \times 10^{-3} \\
1.5 \times 10^{-3} \\
1.5 \times 10^{-3} \\
1.5 \times 10^{-3} \\
6.2 \times 10^{-3} \\
2.9 \times 10^{-3} \\
1.5 \times 10^{-3} \\
2.3 \times 10^{-4} \\
3.6 \times 10^{-4} \\
1.5 \times 10^{-3} \\
4.5 \times 10^{-5} \\
1.2 \times 10^{-1} \\
1.2 \times 10^{-1} \\
6.9 \times 10^{-2} \\
4.5 \times 10^{-4} \\
3.2 \times 10^{-3} \\
3.2 \times 10^{-3} \\
5.9 \times 10^{-3} \\
3.2 \times 10^{-3} \\
3.2 \times 10^{-3} \\
3.2 \times 10^{-3} \\
4.9 \times 10^{-2} \\
6.8 \times 10^{-2} \\
6.8 \times 10^{-2} \\
4.9 \times 10^{-2} \\
6.8 \times 10^{-2} \\
4.9 \times 10^{-2} \\
1.4 \times 10^{-5} \\
1.2 \times 10^{-3} \\
1.4 \times 10^{-5} \\
1.4 \times 10^{-5} \\
9.9 \times 10^{-1} \\
7.3 \times 10^{-1}\end{array}$ & $\begin{array}{l}1.3 \times 10^{-5} \\
1.9 \times 10^{-6} \\
1.9 \times 10^{-6} \\
3.6 \times 10^{-5} \\
3.6 \times 10^{-5} \\
8.3 \times 10^{-4} \\
8.3 \times 10^{-4} \\
8.3 \times 10^{-4} \\
8.3 \times 10^{-4} \\
3.8 \times 10^{-5} \\
3.8 \times 10^{-5} \\
1.3 \times 10^{-5} \\
1.3 \times 10^{-5} \\
7.7 \times 10^{-6} \\
7.7 \times 10^{-6} \\
7.7 \times 10^{-6} \\
7.7 \times 10^{-6} \\
3.5 \times 10^{-5} \\
1.2 \times 10^{-4} \\
5.9 \times 10^{-6} \\
1.3 \times 10^{-5} \\
1.3 \times 10^{-5} \\
7.7 \times 10^{-6} \\
1.3 \times 10^{-5} \\
3.2 \times 10^{-6} \\
3.2 \times 10^{-6} \\
1.8 \times 10^{-6} \\
1.0 \times 10^{-6} \\
1.9 \times 10^{-6} \\
1.9 \times 10^{-6} \\
2.7 \times 10^{-6} \\
1.9 \times 10^{-6} \\
1.9 \times 10^{-6} \\
1.9 \times 10^{-6} \\
2.5 \times 10^{-6} \\
2.2 \times 10^{-5} \\
2.2 \times 10^{-5} \\
2.5 \times 10^{-6} \\
2.2 \times 10^{-5} \\
2.5 \times 10^{-6} \\
3.3 \times 10^{-7} \\
6.1 \times 10^{-7} \\
3.3 \times 10^{-7} \\
3.3 \times 10^{-7} \\
2.0 \times 10^{-1} \\
5.5 \times 10^{-2}\end{array}$ & $\begin{array}{l}6.5 \times 10^{-6} \\
1.3 \times 10^{-6} \\
1.3 \times 10^{-6} \\
2.6 \times 10^{-5} \\
2.6 \times 10^{-5} \\
4.6 \times 10^{-4} \\
4.6 \times 10^{-4} \\
4.6 \times 10^{-4} \\
4.6 \times 10^{-4} \\
2.8 \times 10^{-5} \\
2.8 \times 10^{-5} \\
6.5 \times 10^{-6} \\
6.5 \times 10^{-6} \\
6.0 \times 10^{-6} \\
6.0 \times 10^{-6} \\
6.0 \times 10^{-6} \\
6.0 \times 10^{-6} \\
1.2 \times 10^{-5} \\
5.2 \times 10^{-5} \\
1.8 \times 10^{-5} \\
6.5 \times 10^{-6} \\
6.5 \times 10^{-6} \\
6.0 \times 10^{-6} \\
6.5 \times 10^{-6} \\
3.8 \times 10^{-6} \\
3.8 \times 10^{-6} \\
1.2 \times 10^{-6} \\
8.5 \times 10^{-6} \\
1.1 \times 10^{-6} \\
1.1 \times 10^{-6} \\
3.6 \times 10^{-6} \\
1.1 \times 10^{-6} \\
1.1 \times 10^{-6} \\
1.1 \times 10^{-6} \\
3.6 \times 10^{-7} \\
3.0 \times 10^{-6} \\
3.0 \times 10^{-6} \\
3.6 \times 10^{-7} \\
3.0 \times 10^{-6} \\
3.6 \times 10^{-7} \\
3.7 \times 10^{-8} \\
4.4 \times 10^{-7} \\
3.7 \times 10^{-8} \\
3.7 \times 10^{-8} \\
1.2 \times 10^{-1} \\
4.7 \times 10^{-2}\end{array}$ \\
\hline
\end{tabular}

a Soil represents the current conditons on Bikini Island, $\mathrm{Bq} \mathrm{g}^{-1}$ dry wt.

b Soil represents the combined soil removal and potassium treatment option for Bikini Island, Bq $\mathrm{g}^{-1}$ dry wt. 
Table II. The Maximum Annual Organ Dose Equivalent and Effective Equivalent Rate in $\mathrm{mSv}^{-1}$ for Bikini Island Residents (Assuming Current Island Condition Availability of Imported Foods).

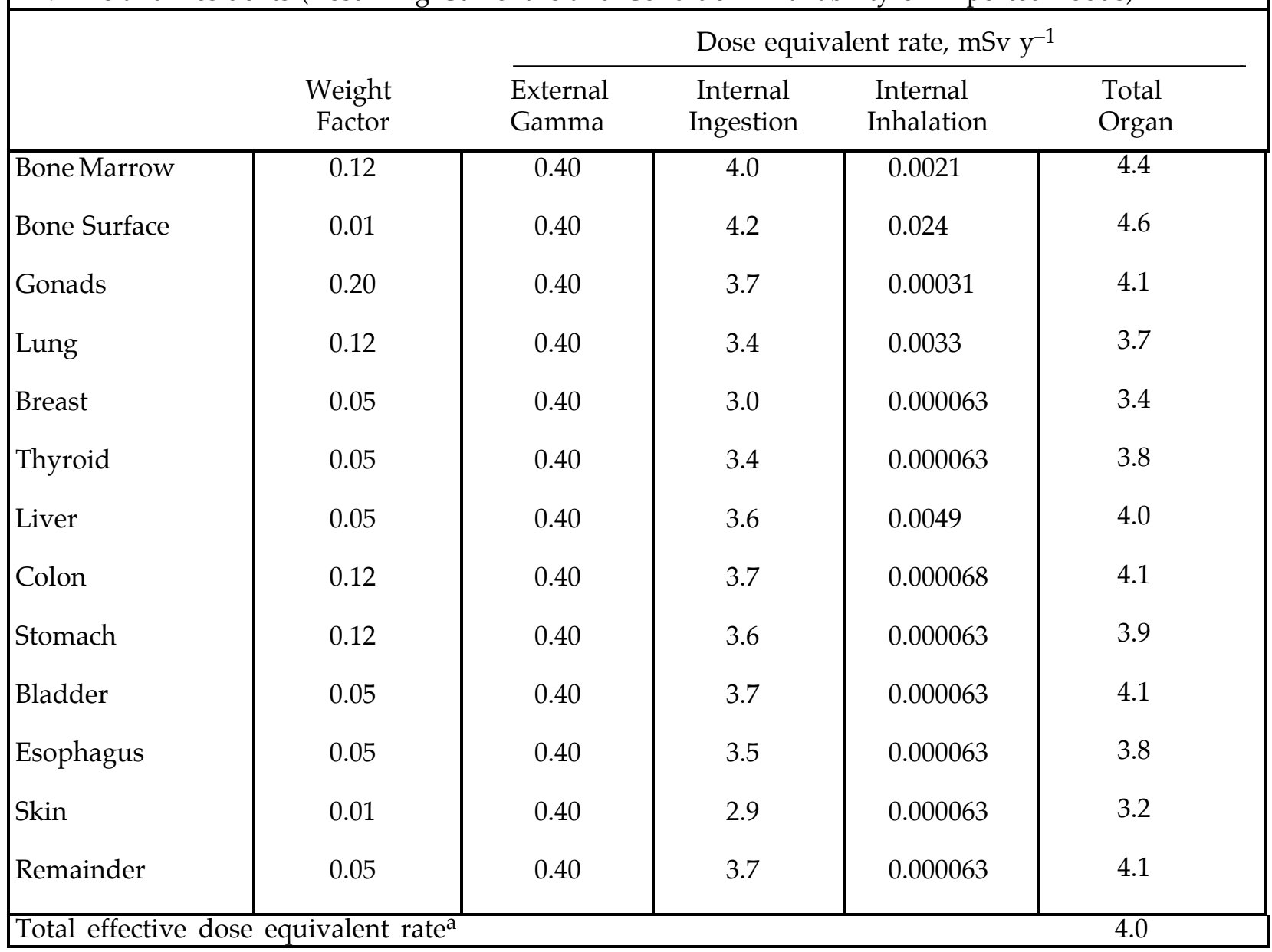

a weighting factor multiplied by total organ dose.

Source: Robison et al, 1997. 
Table III. The 30-, 50- and 70-y Integral Effective Dose for Bikini Island Residents for Current Island Conditions when Imported Foods are Available.

\begin{tabular}{|l|c|c|c|}
\hline & \multicolumn{3}{|c|}{ Integral effective dose, mSv } \\
\cline { 2 - 4 } External & $30 \mathrm{y}$ & $50 \mathrm{y}$ & $70 \mathrm{y}$ \\
& 9.1 & 13 & 15 \\
Internal & & & \\
Ingestion & & & \\
137Cs & 81 & 110 & 130 \\
90Sr & 0.85 & 1.2 & 1.5 \\
239+240Pu & 0.011 & 0.028 & 0.051 \\
241Am & 0.018 & 0.043 & 0.075 \\
Inhalation & & & \\
239+240Pu & 0.069 & 0.16 & 0.23 \\
241Am & 0.050 & 0.11 & 0.15 \\
Totala & 91 & 130 & 150 \\
\hline
\end{tabular}

a The total dose may vary in the second decimal place due to rounding. Source: Robison et al., 1997. 
Table IV. The 30-, 50-, and 70-y Integral Effective Dose for the Various Exposure Pathways for the Imported Foods Available Diet.

\begin{tabular}{|l|c|c|c|}
\hline \multicolumn{1}{c|}{ Exposure pathway } & $30 \mathrm{y}$ & $50 \mathrm{y}$ & $70 \mathrm{y}$ \\
\hline Terrestrial food & 82 & 110 & 130 \\
External gamma & 9.1 & 13 & 15 \\
Marine food & 0.048 & 0.096 & 0.16 \\
Cistern and ground water & 0.15 & 0.21 & 0.25 \\
Inhalation & 0.12 & 0.27 & 0.38 \\
\multicolumn{1}{c}{ Totala } & 91 & 130 & 150 \\
\hline
\end{tabular}

a The total dose may vary in the second decimal place due to rounding. Source: Robison et al., 1997. 
Table V. The 30-, 50- and 70-y Integral Effective Dose for Bikini Island Residents for the Soil Removal/K Treatment Option when Imported Foods are Available.

\begin{tabular}{|l|l|c|c|}
\hline \multicolumn{3}{c}{} & \multicolumn{3}{c|}{ Integral effective dose, mSv } \\
\cline { 2 - 4 } \multicolumn{2}{c|}{$30 \mathrm{y}$} & $50 \mathrm{y}$ & $70 \mathrm{y}$ \\
\hline External & 3.6 & 4.9 & 5.7 \\
Internal & & & \\
$\quad$ Ingestion & & & \\
137Cs & 5.3 & 7.2 & 8.5 \\
90Sr & 0.84 & 1.2 & 1.5 \\
239+240Pu & 0.011 & 0.028 & 0.051 \\
241 Am & 0.011 & 0.026 & 0.045 \\
Inhalation & & & 0.14 \\
$239+240 \mathrm{Pu}$ & 0.043 & 0.10 & 0.11 \\
241 Am & 0.04 & 0.08 & 16 \\
Totala & 9.8 & 14 & \\
\hline
\end{tabular}

a The total dose may vary in the second decimal place due to rounding. Source: Robison et al., 1997 
Table VI. Comparison of Estimated Effective Doses for Two Options, with Imported Foods Available.

\begin{tabular}{|l|c|c|}
\hline \multicolumn{2}{|c|}{ Island Status } & \multicolumn{1}{c|}{$\begin{array}{c}\text { Combined K Treatment } \\
\text { and Soil Removal }\end{array}$} \\
\hline $\begin{array}{l}\text { Maximum average } \\
\text { annual effective dose, mSv }\end{array}$ & 4.0 & \\
& & 0.41 \\
30 y integral dose, mSv & 91 & 9.8 \\
50 y integral dose, mSv & 130 & 14 \\
70 y integral dose, $\mathrm{mSv}$ & 150 & 16 \\
\hline
\end{tabular}

Source: Robison et al., 1997 


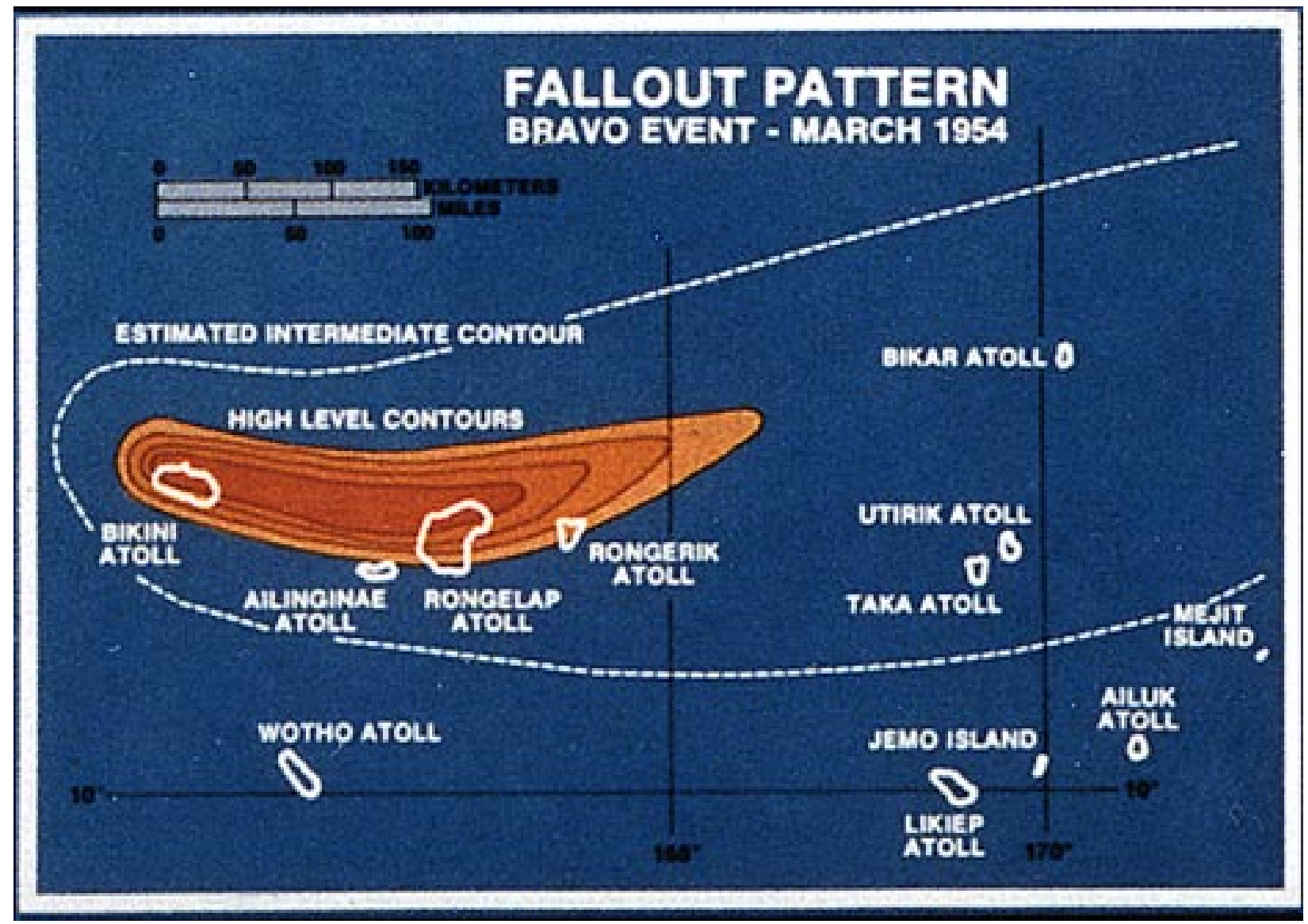

Figure 1. A map of the Marshall Islands showing the location of the two nuclear test sites, Bikini and Enewetak Atolls, and the fallout pattern from the BRAVO test. 


\section{Bikini Island \\ Median Concentration in Soil}

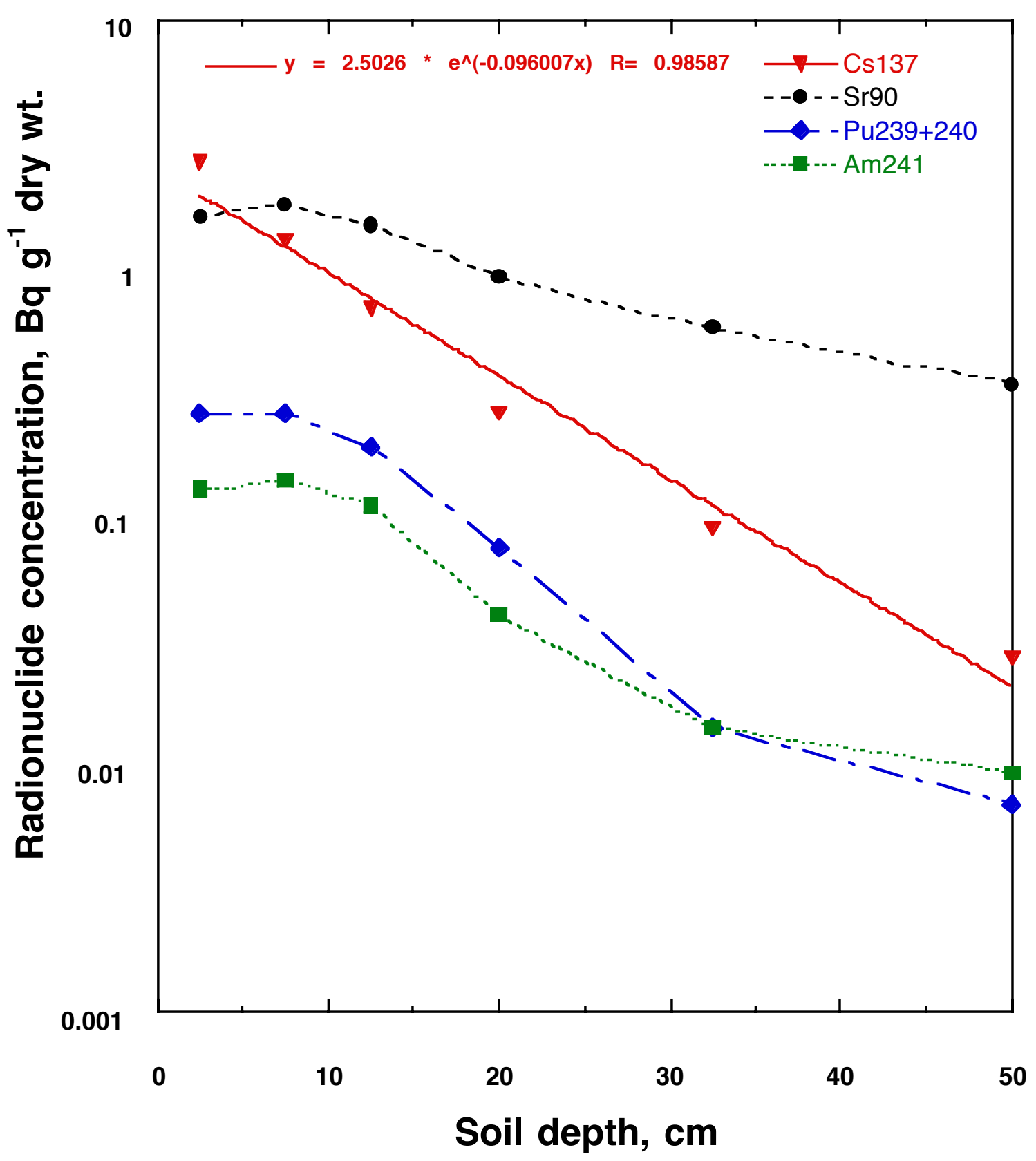

Figure 2. The mdian radionuclide concentrations as a function of soil depth from 240 soil profiles collected at Bikini Island. 


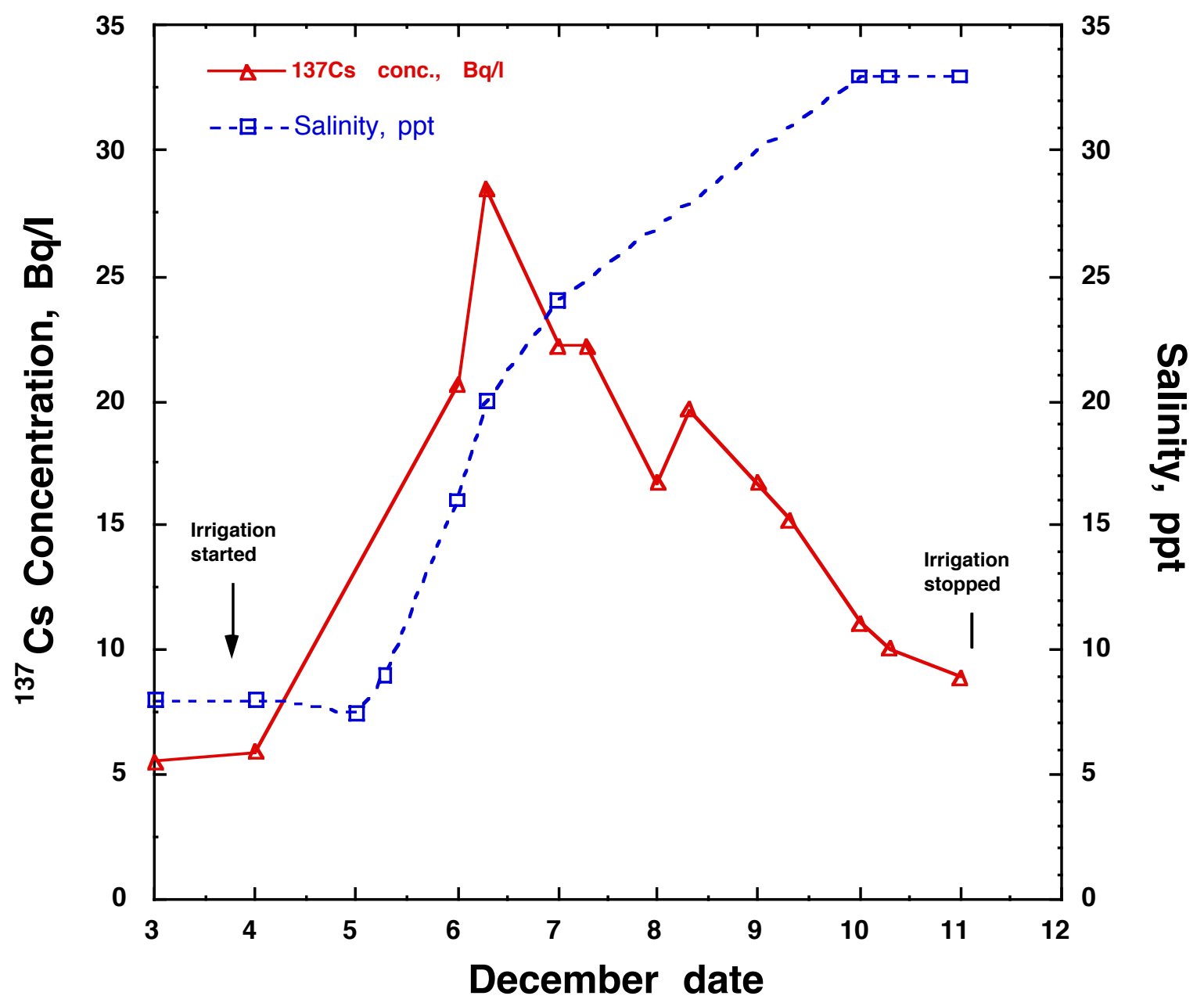

Figure 3. The ${ }^{137} \mathrm{Cs}$ concentration and salinity in ground water during salt water irrigation. 


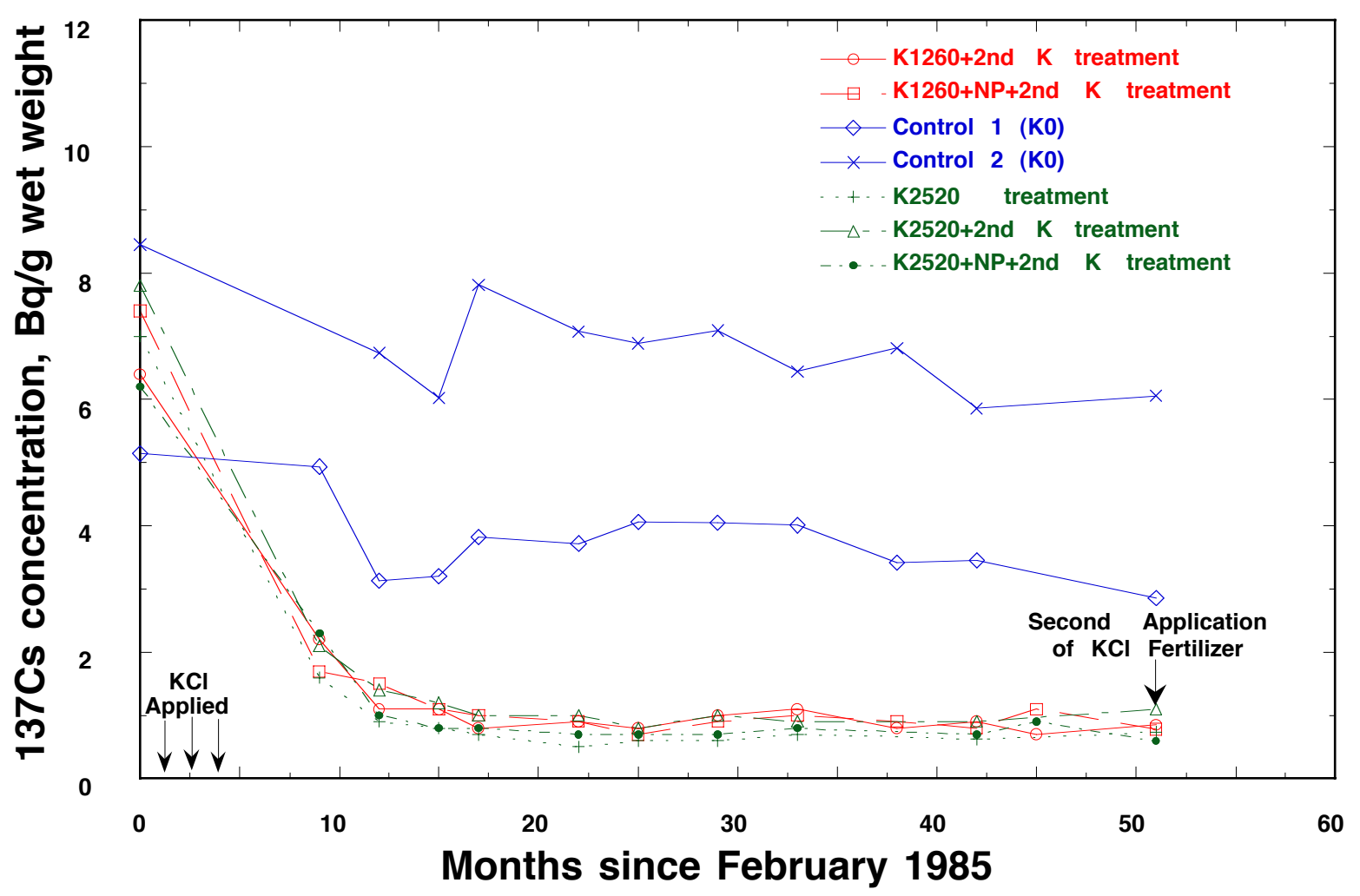

Figure 4. The effect of Potassium added to the surface soil on the ${ }^{137} \mathrm{Cs}$ concentration in coconuts. The numbers in the figure legend refers to the $\mathrm{kg} \mathrm{ha}^{-1}$ of applied $\mathrm{K}$. K1000 $=1000 \mathrm{~kg}$ of K per hectare. The roots of coconut trees extend much further than originally realized when this experiment was established. The roots from the control trees have reached into $\mathrm{K}$ treated areas thus causing the observed decline in the controls. Controls from differently designed experiments, where roots from control trees definitely had no access to K, show no decline over a similar period of time. 


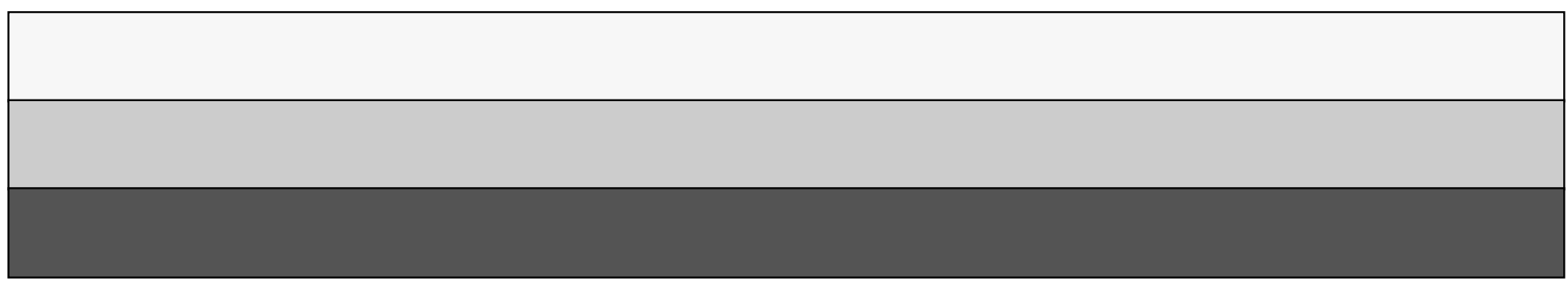

